\title{
New finds of stegosaur tracks from the Upper Jurassic Lourinhã Formation, Portugal
}

Octávio Mateus, Jesper Milàn, Michael Romano, and Martin A. Whyte

Acta Palaeontologica Polonica 56 (3), 2011: 651-658 doi: http://dx.doi.org/10.4202/app.2009.0055

Eleven new tracks from the Upper Jurassic of Portugal are described and attributed to the stegosaurian ichnogenus

Deltapodus. One track exhibits exceptionally well-preserved impressions of skin on the plantar surface, showing the stegosaur foot to be covered by closely spaced skin tubercles of ca. $6 \mathrm{~mm}$ in size.

The Deltapodus specimens from the Aalenian of England represent the oldest occurrence of stegosaurs and imply an earlier cladogenesis than is recognized in the body fossil record.

Octávio Mateus, [omateus@fct.unl.pt] Departamento de Ciências da Terra (CICEGe-FCT), Universidade Nova de Lisboa, Lisbon, and Museu da Lourinhã, Rua João Luis de Moura, 2530-157 Lourinhã, Portugal; Jesper Milàn [jesperm@oesm.dk ] Geomuseum Faxe, Østsjællands Museum, Højerup Bygade 38, DK-4660

Store Heddinge, Denmark \& Department of Geography and Geology Geology Section, University of Copenhagen, Øster Voldgade 10, DK-1350 Copenhagen K, Denmark; Michael Romano [m.romano@sheffield.ac.uk] and Martin A. Whyte [m.a.whyte@sheffield.ac.uk] Sheffield Dinosaur Track Research Group, Department of Geography, University of Sheffield, Dainton Building, Brookhill, Sheffield, S10 2TN, UK.

This is an open-access article distributed under the terms of the Creative Commons Attribution License (for details please see creativecommons.org), which permits unrestricted use, distribution, and reproduction in any medium, provided the original author and source are credited. 
